\title{
The Future of the Subaltern Past: Toward a Cosmopolitan 'History from Below'
}

\author{
Victoria Heftler $^{1}$
}

I

Pastness is a mode by which persons are persuaded to act in the present in ways they might not otherwise act. Pastness is a tool persons use against each other. Pastness is a central element in the socialization of individuals, in the maintenance of group solidarity, in the establishment of or challenge to social legitimation. Pastness therefore is pre-eminently a moral phenomenon, therefore a political phenomenon, always a contemporary phenomenon. ${ }^{2}$

'History from below' refers to a terrain well known to Left historians, and with forty years of maps and compasses and guidebooks to make us familiar with its structural features and its inhabitants, it might not seem to warrant a new exploration. But am I alone in feeling that more than ten years of theoretical debate and polemic has made the exact location of 'below' surprisingly vague? Just where is it, who occupies it, is its population growing? Who is interested in its past and its present? What kind of boundary separates it from its hostile neighbour, 'above'? What kinds of reconnoitering would make more effective our strategic interventions on its behalf? This essay is an attempt to look toward the future of the subaltern past.

Two premises about the relationship between historiography and politics would seem to underlie the project of 'history from below,' and they lead me to a sketch of an argument. The first premise, that historiography has political effects, should be uncontroversial among Left historians. We do not simply remember; we are reminded, and this reminding may serve to construct or to undo political solidarities, to legitimate or to undermine existing institutions, to induce quiescence or to incite action. It is this moral and political dimension of historiography, acutely delineated by Immanuel Wallerstein in the passage quoted above, that places a special burden on the Left historian, who, as Walter Benjamin put it, must strive "to wrest tradition away from the conformism that is about to overpower it" and "to fan the spark of hope in the past," that is, to inspire and guide political action. It is this moral and political dimension of historiography that informed the earliest work in 'history from below,' and that continues to make debates about the principles that guide our practice - on the relative efficacy of things and representations, for example, or on the relative merits of women's history and gender history - of such pressing importance to us. 


\section{Left History 5.1}

If we share the view that historiography is and should be political, a second (perhaps more controversial) premise underlying 'history from below' is that both the production of historical knowledge and its political effects are contextsensitive. 'Presentism,' like political commitment, may be an epithet hurled at some historians by their more 'objective' colleagues. Too explicit a reference to the plays of power and interest in the present, it seems to some, give away our pretensions to 'neutrality' and 'truth.' It might reveal that which seeks to hide, as de Certeau has put it, "behind the picture of a past, the present that produces and organizes it." 4 The concerns of the historian about the past, however, are always formulated in a present. In Wallerstein's words, pastness is "always a contemporary phenomenon"; in Greg Dening's, "histories always have this double entendre. They refer to a past in making a present." $\mathrm{O}$ Or as Benjamin puts it, the historian must "seize hold of a memory as it flashes up at a moment of danger." Just which memory flashes up will vary from one moment of danger to another. Our present is, I assume most would agree, quite a different moment of danger than that faced by Thompson, Hobsbawm, Rudé and other creators of the genre of 'history from below.'

While I will emphasize in much of the discussion below the contrast between our moment of danger and earlier ones, I want to make clear what I think has not changed. Whatever "post-" might apply either to our theory or our era, we do not inhabit a "post-subordination" world. Whatever revisions we might have made, then, in our explanations of social causality or in our models for economic restructuring or in our confidence in our own powers to know, the moral core of our commitment to redress subordination did not disappear along with a wall or an empire or a 'science.' That line across which, in the words of one seventeenth-century Ranter, "your slavery is their liberty, your poverty is their prosperity," should provoke our action as readily today as it did a decade, a generation, centuries ago.

The current socio-political context nevertheless differs in important ways from that of the classical period of 'history from below' in the 1950s and 60s, and from the period of its expansion and revision in the 1970s and 80s. New configurations of global capitalism, mass migration and mass mediation have fundamentally re-shaped the terrain on which politics - including the politics of historical knowledge - is conducted. ${ }^{7}$ This suggests a new project for historians on the Left. Given that Left historiography is and should be political and presentist, and that subordinations demand redress, the questions I consider in the pages that follow are these: How might we achieve a more effective praxis of knowledge-politics? What sort of Left historiography might contribute to an

effective political response to the practices of subordination which so deeply 
divide our "globalized" society? How should we "seize hold of a memory as it flashes up" at this particular moment of danger? How might historians help to construct membership in a group-for-itself which will struggle effectively against subordination in all of its forms?

The particular point of re-thinking I suggest is a thorough-going questioning of the practice of taking the national as natural. The great preponderance of historiography, from widely divergent theoretical and political perspectives, nevertheless shares an often tacit reliance on the nation and/or the nation-state as its fundamental organizing principle. ${ }^{8}$ A quick perusal of the deployment of state-based nouns (do they mean to imply homogeneity?) or state-based adjectives in the titles of books, articles, journals, and university courses, in the organization of book reviews or the delineation of 'fields' for mastery by graduate students, or in the Library of Congress cataloging categories, might show us how difficult it is to escape this system of organizing pastness. Moreover, this is often as true of socialist, feminist, black, aboriginal, or post-colonial 'history from below' as it is of liberal and conservative 'history from above.' While many historians, then, have not had deliberately nationalist purposes, we may not assume that, without the purposes, the practices don't follow. But do socialist historians see the same state categories from below that their liberal and conservative colleagues do from above? And are these categories perhaps fetishized constructions which now impede emancipatory politics?

The members of the Communist Party Historians' Group in post-war Britain worked to develop a Marxist interpretation of English history, thus extending a line of historiography that had begun with A. L. Morton's A People's History of England (1938). This body of work was intended not only to include subaltern actors, but to show elite action from a subaltern perspective, and sometimes to show it to a subaltern audience. It has served to 'remind' readers that those who did not hold political and economic power in the past were nevertheless historical agents from whose actions both lessons and inspiration might be drawn. ${ }^{9}$ The History Workshop movement demonstrated that the subaltern could not only make history but could make historiography as well. Their History Workshop Journal, founded in 1975, represented, as Stuart Hall has put it, "a collective experiment in the democratization of history writing." 10 Moreover, this democratization was to be achieved not only with respect to the authors of historical writing, but to the very language in which it would be written. ${ }^{11}$ One of the most notable influences of British Marxist historiography has been in India, where Ranajit Guha, and others, sought to mount a critique of Indian nationalist historiography. The independence struggle was not, Guha and his colleagues would demonstrate, solely an elite affair, nor was the resulting 


\section{Left History 5.1}

post-colonial Indian state the only bounded community thinkable by, or capable of inspiring action from, subalterns throughout the sub-continent. ${ }^{12}$

But, perhaps ironically, a social history which meant to challenge a political history which was nationalist almost by definition, itself often selected its subjects, posed its questions, and framed its narratives 'nationally.' Paul Gilroy has pointed out that Marxist analysis, including that which influenced British social historians, has often understood both "modes of material production and political domination as exclusively national entities."13 Thus, in E. P. Thompson's The Making of the English Working Class, we see a vivid and moving depiction of struggle from the subordinates' perspective, but it is, nevertheless, 'struggle in one country. ${ }^{14}$ Why would the project of history from below remain so resolutely focused on England for a generation after the war? Might one answer be that its 'reminding' was being done when the terms of its subjects' inclusion and membership in British society were being pressed in new notions not of political but of social citizenship? Thompson's fervent belief in workers' capacity for democratic collective expression and action - in contrast both to de facto exclusions in British society and to Stalinist centralism within the Communist Party - informed his contribution to history from below. Part of this effort, however, entailed an adherence to those twin pillars of modernist political thought: nationality and rationality. ${ }^{15}$ Thus, although Bryan Palmer has reminded us of E. P. Thompson's lifelong commitment to internationalism, Thompson's historical works nevertheless have, as many have observed, a decidedly national focus. ${ }^{16}$ In considering our current historiographical task, should we not ask just what it is that leads an internationalist to write national (if not nationalist) histories? The need to realize in our histories Thompson's internationalist ideals is more pressing than ever, given that the nation-state cannot now, if it ever could, suffice in mapping the struggle against subordination.

In the revisionist 'history from below' of the 1970 s and 80 s, when 'universalist' notions of citizenship were increasingly seen to be nevertheless coded male, white, heterosexual, 'dominant-ethnic-group,' not coincidentally we saw, in what may be seen as the historiographical expression of 'identity politics,' new forms of social history devoted not to 'the people' and its 'universal' expression, the working class, but to women, blacks, aboriginal peoples, colonial subjects. Many socialist historians found at least some aspects of this expansion of the terrain of social history to represent a dire threat to an emancipatory knowledge-politics. ${ }^{17}$ I would argue that many of the revisionist 'secondwave' histories from below may be seen to share in the danger of identity politics more generally: of a new, albeit 'lower-level,' essentialism. As Lawrence Grossberg has put it, "a politics of identity reifies and sometimes even fetishizes 
the differences between fractions of the population, undermining any possibility that such fragmentation can be appropriated as a historical resource." 18 But in spite of such fragmentation, in many histories the 'pieces' nevertheless continue to be collected in national containers.

To understand the socio-political contexts in which these shifts in the focus of 'history from below' took place, we might look for parallels in the trajectories of other political movements. Paul Gilroy has characterized the structure of W. E. B. Dubois' Souls of Black Folk as reflecting a move from struggle for an end to slavery (an international struggle), to struggle for an inclusive citizenship which would realize the United States' liberal promise (that is, a national project), to withdrawal and search for an autonomous social and political space in the face of disillusionment with that liberal promise (a sub-national project). ${ }^{19}$ Peter Waterman has drawn a somewhat similar trajectory for the women's movement, where an initial position of exclusion from national politics led to a lively internationalism (here he compares it with labour internationalism), which was then forgone for a national and/or sub-national focus with 'second wave' feminism. ${ }^{20}$ I would suggest that these same shifts may be seen in history from below. Are we necessarily stranded, then, between the Scylla of national and the Charybdis of sub-national essentialisms? Given that state membership is neither uniform in its meanings and entitlements nor stable over time, it would seem a poor container for social history even were a system of sovereign nation-states deemed to contain all the world's politics. And while presumptions of congruence between territory, culture and state may once have been part of our common sense, ${ }^{21}$ this is now much less tenable, and an "enabling" pastness will reflect the blurring and crossing of once taken-forgranted boundaries. Reorganizations of production and of consumption imply the need for a reorganization of historical knowledge, specifically one which seeks to understand and to transcend the naturalization of nationality. Moreover, given that the nation-state is a powerful actor in difference-production, including the construction of national and sub-national identities, "historians-frombelow' might have a particular stake in questioning its procedures and its effects, not least in our own work.

My intention here is not to criticize past historians anachronistically for some failure of imagination or some avoidable loss of relevance. Rather, as Thompson sought to do, I hope to show how a reliance on naturalized categories can inhibit the formulation of a genuinely emancipatory project. Can we find an effective contemporary idiom in which to 'remind' social actors of those "sparks of hope" in the past which could inform a collective response to new regimes of subordination? These regimes cannot be effectively challenged, I argue, with 
either the false boundaries and false uniformities of undifferentiated membership in a state-bounded class nor with the lingering essentialisms of identity, however construed. Today's historians-from-below might thus tell new stories, tell them in new terms, and use new (or newly valorized) methods in producing them.

Arjun Appadurai has said of the current conjuncture that "as the shapes of cultures grow less bounded and tacit, more fluid and politicized, the work of cultural reproduction becomes a daily hazard." 22 But does this conjuncture not present the historian with an opportunity as well as a threat? While old narratives may have lost some of their salience, new possibilities present themselves for interrupting taken-for-granted hegemonies, for "wresting tradition away from conformism." My suggestion in this essay is that in place of subaltern histories which are either narrowly national or disconcertingly fragmented, we might present a pastness of subaltern cosmopolitanism, whereby the most crucial boundary for critique, for struggle and for redress is neither nation nor class, neither gender nor race, but rather simply that between dominator and dominated, oppressor and oppressed, wherever they may be.

Perhaps I should clarify here my use of the terms 'subaltern' and 'cosmopolitan.' I use the term 'subaltern' following the so-called 'Subaltern Studies' school of South Asian social history. In his preface to the first volume of this collective's work, Ranajit Guha says that "the word 'subaltern'...stands for the meaning as given in the Concise Oxford Dictionary, that is, 'of inferior rank.' It will be used...as a name for the general attribute of subordination [emphasis added]." He goes on to say that "subordination cannot be understood except as one of the constitutive terms in a binary relationship of which the other is dominance, for subaltern groups are always subject to the activity of ruling groups, even when they rebel and rise up. ${ }^{23}$ Here I use the term 'subaltern' to point to all those who are on the receiving end of harm: of the violence, theft, exploitation, marginalization, and domination that are felt, endured and resisted by subordinates in widely varying social locations.

I use the term "cosmopolitan' - "belonging to all parts of the world"; "not restricted to any one country"; "free from national limitations or attachments"to echo Marx and Engels' point in The Communist Manifesto: "The bourgeoisie has through its exploitation of the world market given a cosmopolitan character to production and consumption in every country. To the great chagrin of Reactionists, it has drawn from under the feet of industry the national ground on which it stood." 24 The current state of globalization, mass migration and mass mediation has given to subalterns, more than ever, a de facto cosmopolitanism that should, I argue, be actively embraced in their political struggles. 
Subordination is no respecter of borders - less so now than ever. But solidarities, too, may be imagined from a distance. What sorts of historical narrative might inspire new recognitions which would allow for a cosmopolitan articulation not only of resistance to subordination but also of a vision for its transcendence? I will suggest, in Part II, some reasons for the lingering essentialisms to be found in the work of even the most committed historians-from-below and some analysis of their political implications; in Part III, I will sketch out some possible directions from which to approach a cosmopolitan 'history from below,' arguing not for a celebration of difference but for an historical examination of difference-producing practices. ${ }^{25}$ Such an approach will, I hope, encourage solidarities across previously naturalized social divides. It may offer what one commentator on Benjamin has referred to as "an enabling remembrance." 26

II

The different academic disciplines take these forms (the state, money, the family) as given and so contribute to their apparent solidity, and hence to the stability of capitalist society. To think scientifically is to criticise the disciplines, to dissolve these forms, to understand them as forms. ${ }^{27}$

Why is it that historiographies of all political commitments revert to nationstate belonging (or something similar) as their organizing principle? Why do 'historians-from-below' nevertheless organize their work on the basis of social identities which are the outcomes of the very processes of power they criticize? In so doing, they reinforce essentialisms and foreclose a more cosmopolitan vision of, as Fox-Genovese and Genovese have put it, "who rides whom and how." 28 Can we identify some of the difficulties facing those who would construe subaltern pasts in cosmopolitan ways? One set of challenges is structural, and can be found in the methods of professional historiography, on the one hand, and in our emphasis on subaltern agency, often construed as resistance, on the other. Each of these factors leads the historian into the arms of the nationstate. A second set of challenges can be found in language: what might be called the 'curse of Babel,' that is, the limits to our linguistic competence beyond our native tongue, on the one hand, and the particular metaphors - those of blood and belonging - which frame so much of our understanding of pastness. The first two are challenges particular to the historian, while the second two affect historians, their readers, and political actors more generally. I will sketch out each of these in turn, with particular emphasis on the problems each poses for the emancipatory knowledge-politics of 'history from below.' 


\section{Left History 5.1}

The professional practices and protocols of academic historiography have deep structuring effects on what we produce and disseminate (as well as what we 'consume'), even as we strive to be 'oppositional.' As de Certeau has put it, our professional community "is also a factory, its members distributed along assembly lines, subject to budgetary pressures (hence dependent on political decisions) and bound by the growing constraints of a sophisticated machinery (archival infrastructures, computers, publishers' demands, etc.)." 29 One effect of these institutional constraints is that we are led again and again to the nationstate. This is true even when 'political history' is abandoned in favour of 'social history,' and even when a 'top down' perspective is replaced by one 'from the bottom up.' When, as Joan Scott puts it, archives "for many social historians ... are sacred places where one culls from documents 'facts' about the past," ${ }^{30}$ the state's own implication in both the production and the retention of, and the granting of access to, archival material puts the state squarely in the role of 'gatekeeper.' And while Benedict Anderson mentioned the census, the map and the museum as vehicles for communicating the 'reality' - and eventually the 'naturalness' - of the state, ${ }^{31}$ all of the material produced, collected and reverentially stored by the state - court proceedings, tax rolls, war records, legislation, administrative correspondence, colonial reports - serves to create the illusion that the state is both a necessary and a sufficient container for the lives of its citizens. And if there is a necessary tension between capitalism's national and transnational forms and forces, this tension is repressed in favour of the national in the institutional location of historical records.

At least to the extent that the historian is limited to the archives of one nation-state, the role of the state in structuring possible histories goes a long way toward revealing the irony in Ernest Renan's remark that "progress in historical studies often constitutes a danger for nationality" in that it exposes the "deeds of violence which took place at the origin of all political formations." For even if all the 'facts' of that violence are recorded and maintained (which is often unlikely), their categorization and construal may code such 'violence' as heroic sacrifice, may label its victims as 'enemies,' and a generation may be more than enough to silence those who might remember it otherwise. This determines in fundamental ways the kinds of history that can be conceived of, much less realized. Then, as Homi Bhabha suggests, "being obliged to forget becomes the basis for remembering the nation." 32 And while no set of records will be free of the play of power and interest, reading from more than one perspective at least encourages the recognition of the moral and political ambiguities of categorization and construal.

What some would claim to be the 'raw material' of historiography is thus by 
no means in an 'unprocessed' condition. It is embedded in particular institutional practices and in particular regimes of categorization. These all 'place' the social actors to whom they refer in particular ways, as they leave others with no 'place' in history at all. To use Pierre Nora's noteworthy term, some actors command more "historical capital" than others. ${ }^{33}$ To listen for echoes of the deeds and the voices of those who have been as deprived of social memory as they have been deprived of other social goods is to listen, as we have learned from Sherlock Holmes, for "the dog that didn't bark in the night." ${ }^{34}$ Moreover, this inequality of recorded presence may be even more striking between nationstates than within them. The subaltern Albanian may have left fewer print traces by far than the English handloom weaver. Is one's past more worthy of recall than the other's? Is one more revealing of exploitation, marginalization and harm?

Even if we presume that national belonging is a (or the) crucial organizing principle for historical memory, however, changes in state boundaries present a problem. Three situations may arise: (1) a region may not have a long history as a separate state (Belgium, for example) ${ }^{35}$ (2) the region may no longer exist as a state (Prussia, for example, or the Soviet Union); (3) the region may have been a sub-national unit within more than one state (Silesia, for example). And in all three of these cases, the very lack of those things that the state does so well recordkeeping, counting - or their complexity and fragmentation - may make us long for the constraints of centrally imposed categories: at least then there would be something to deconstruct. It is far harder to be a historian of Silesia, say, than of England, and not just because you need both German and Polish. This is too bad, because important stories will be missed.

But if we must work against the assumptions that states are homogeneous and that they last forever, we need also to subvert the assumption that actors are permanently 'stated.' Of course, we know that cross-border movement has been the rule rather than the exception throughout the period in which state borders have been important. The histories of such movements, however, tend to be structured as if the states were the subjects (or at least that any actors who happen to occupy their space were the subjects), instead of putting it the other way round: that the men and women are the subjects, in whatever state they happen to find themselves. The historical treatment of membership lost and membership gained curiously lacks a sense of the complexities and the conflicts of relationship these membership changes embody. Paul Gilroy meets this challenge in The Black Atlantic, with what he calls "the image of ships in motion across the spaces between Europe, America, Africa and the Caribbean as a central organizing symbol." ${ }^{36}$ But if this work has met the call for a de-national- 


\section{Left History 5.1}

ized subaltern history, a history of 'hybridity,' it may be seen to take us only part of the way to a genuinely cosmopolitan history from below. It is, I would argue, still vulnerable to essentialist identifications. ${ }^{37}$

The state's role as gatekeeper with respect to traces of the past is especially crucial for 'history from below,' given that, in most places and times, the uneven distribution of literacy and leisure necessarily concentrates writing about one's self and one's group among the privileged classes. Subordinates have needed to provoke the interest of their superiors in order to find their way into the archive, and that 'interest' has been stimulated in necessarily patterned ways. While a great deal of very creative "brushing history against the grain" has been done by 'historians-from-below' working with, for example, court records, we are nevertheless left with the virtually unanswerable question, "who has been kept from remembering what?' by the state's particular inscription of 'noteworthy' actors and events. And this brings us to the second challenge to a more cosmopolitan history from below: the Left historian, like the state, takes a particular interest in those who defy the state, who resist its impositions. That we see promise where the state sees problems should not obscure the fact that our selections for attention mirror the state's own. In Conan Doyle's story, the "dog that didn't bark in the night" was silent, we might remember, because it knew the criminal and did not feel threatened by his presence. ${ }^{38}$ What might this suggest about the subalterns who aren't found in the archives of the state?

Such an emphasis on resistance to the state, stemming not only from the availability of archival traces but also from the oretical understandings of social transformation and from the search for subaltern agency, may limit the political efficacy of history from below. It may not only restrict our sense of which subalterns are interesting (as feminist historians have been arguing for a long time), but its focus on the 'counter-blows' from below rather than the blows from above may be ultimately disempowering. In focusing on what are, after all, losing propositions, we may celebrate failed actions at the expense of provoking more successful ones. And in our disappointment with those supine subalterns who don't resist, we may miss the opportunity to show just how those subordinates are laid low.

The 'curse of Babel,' whereby our ability to master languages is painfully finite, means - given the demand for primary research - that the historian from below is likely to 'go below' in only one country or two, just as it means that the readers of history from below are likely to read works in only one language or two. The English-speaking historian is either restricted to English or to one of the European languages deemed 'central' to the Western experience, or is consigned to a ghettoized 'area,' with its own journal and its own section of book 
reviews in more eclectic journals, the work to be circulated only among those in that 'area.' If one does the history of Bengal, for example, one may become a sort of honorary Bengali, sharing stories with those to whom they 'really' belong. That these Bengali stories might have something interesting and important to say to a historian of China is a question unlikely to be raised. Just why one of the British Marxist historians - Eric Hobsbawm - most notably did not restrict his histories to England or to any other nation-state is, I think, in part a function of his polyglot central European background. ${ }^{39}$ And the effects of 'Babel' can be found not only in limiting the stories we know and the comparisons we are competent to make, but also in limiting the range and depth of our political identifications and those of our readers. In all of those cases where political and linguistic borders have been contested and contingent over long periods, for example, linguistic specialization can mean 'choosing a side' in very complex struggles of subordination and resistance. One illustration can be found in the striking contrast in English-language histories dealing with the Atlantic Coast of Central America, the so-called Miskito Coast, between those based on Spanish-language archives (in Spain or in national archives in Central America) and those based on English-language archives in Britain and the Caribbean. One's understanding of a host of political issues in Sandinista Nicaragua - of Marxist regimes' ability to understand the political aspirations of indigenous peoples, for instance, or of the local historical memories mobilized by the U.S. in the 'contra' war - will find strikingly different bases in these two bodies of work. ${ }^{40}$

And while language in this literal sense serves to limit the horizons of historians and political actors alike, one particular discourse in accounts of the past has, I would argue, a more insidious effect on our political affiliations. This discourse of pastness, both professional and popular, is typically based on metaphors of "blood and belonging." It is a language of genealogy, of "Abraham begat Isaac"; a language of inheritance, of 'legacy': the legacy, for example, of black slavery. When such language moves beyond descent, it is to the 'fictive descent' of the adopted child, the 'naturalized' citizen who may be 'welcomed' into the family, but who will later pass on that bclonging to his or her 'natural' descendants. Adoption thus does not replace the system of blood descent, but, in fact, sustains it. Moreover, this language is not simply some recent confounding of Weberian modernization: it has been part of the common talk of pastness in eras premodern, modern and postmodern.

Modern political sociologists did, as we know, predict the disappearance of ethnicity as the social basis of politics, just as modern political philosophers once prescribed it. In a world based on universal rights and on popular sover- 
eignty, citizens, freely communicating and associating, would contest and decide the terms of their co-existence. Political affiliations based on inheritance would give way to those based on interest and voluntary association, just as political institutions based on force would give way to those based on ascendant legitimation and consent. That things have not followed these predictions has been the focus of a great deal of recent analysis. What few seem to have noticed, however, is that histories have almost always been told in the language of blood and belonging. That there is an irony here, or at least a mystery, is suggested by this comment by an anthropologist: "Historicity...is the nightmare of the ethnographer, the constant reminder that the groupings one tends to take for granted are human creations, changing results of past and present processes." 41 That historians themselves - despite the debates inspired by Hobsbawm and Ranger's Invention of Tradition, ${ }^{42}$ and despite theoretical challenges to the use of unexamined categories - forget just this result of historicity, should lead us to suspect that something powerful is afoot here: Appadurai, for example, may vividly describe deterritorialization but still writes about "genealogy"; Benjamin writes about "enslaved ancestors."

And why does this matter? Since "a metaphorical concept can keep us from focusing on other aspects of the concept that are inconsistent with the metaphor," ${ }^{43}$ such language, I would argue, encourages essentialism and naturalizes some forms of social solidarity (those based on descent) while it obscures the possibility and the value of others (ones based on similar experience). The language of blood and belonging limits not only what stories seem worth telling and hearing ("who are they to us?") but also what insights might be drawn from them (an emphasis on 'nature' obscures the uneven terms and results of 'nurture'). Essentialism always obscures the play of power. While I would argue that such renderings have always been politically harmful, the current global condition of mass migration and mass mediation (of 'virtual belonging') means that they are particularly so at our 'moment of danger.' I would argue, then, for a desanguinization in the language and the logic of historiography, and particularly of history from below.

But the metaphors of organic connectedness have further effects in the selfunderstanding of 'historians-from-below,' who are, by virtue of their position as professional scholars, not themselves 'below.' Academic historians, after all, enjoy what one scholar has referred to as "the leisure of the theory class," 44 and claim subaltern status for themselves with some difficulty. But they may be, as it turns out, the daughters of silenced or marginalized women, the sons of factory workers, or the great-great-grandsons of slaves. Their own 'descent' may be understood to give them both the desire and the 'authority' to speak for 
some particular subalterns. These ambivalences within the social location and the self-understanding of some 'historian-from-below,' I would argue, have served to blur the lines in their work between dominator/dominated, between oppressor/oppressed, in understandable but politically dangerous ways. Lawrence Grossberg has made this important point:

According to identity politics, only direct experience can legitimate commitment and any other involvement is suspect. Without a theory of commitment which is somewhat independent of identity, it is impossible to understand the possibilities of active political opposition which transcends any specific identity or local struggle. ${ }^{45}$

I will argue for an approach to historiography which contributes to the conscientization of the historian as well as of her audience, one which opens up her own vision of her connection with her subjects and of the moral and political challenges which confront us. In doing the research and the writing, her own identifications and insights should change, as she hopes they will for her readers and for all those who might ultimately be influenced by her work.

These four constraints on a cosmopolitan history from below - the professional protocols of academic historiography, our emphasis on state-defined resistance as politically interesting, the limits to our linguistic skills, and our susceptibility to metaphors of 'blood and belonging' - lead us and our readers toward some social and political identifications and actions, while they lead us away from others. What might offer a different vantage point from which to intervene in the politics of historical knowledge?

III

If respect for the condition of the homeless (or the racially or sexually oppressed) does not imply respect for the social processes creating homelessness (or racial or sexual oppression), then identity politics must operate at a dual level. A politics which seeks to eliminate the processes which give rise to a problem looks very different from a politics which merely seeks to give full play to differentiated identities once these have arisen. ${ }^{46}$

What would a 'history from below' look like that does not restrict itself to national (or sub-national) boundaries? In what ways might the historian break the rules of professional respectability in order to inspire new solidarities, both for herself and for her readers? What language would such a history use, if not 
the language of descent and biological likeness? I offer two related suggestions. First, we might emphasize comparative histories, but extend that genre (often limited in scope and sometimes disparaged by 'specialists') to what I would call 'juxtapositional history. ${ }^{17}$ This would place, side-by-side, several (or many) thematically related 'stories,' not all of which, of course, could be based on primary research. The stories might - in fact, should - come from a variety of times and places and be based on original work in a variety of languages, but should differ from standard comparative histories in offering more stories in one place, and from standard works of synthesis in leaving far more open-ended the insights and conclusions to be drawn from the juxtapositions. Richard Vann has provided some interesting ideas on the relationship between narrative form and subalternity that might encourage such an approach. Long narrative forms, he says, belong to other classes. Neither the aristocratic epic nor the bourgeois novel have an analogue in the story-telling of ordinary people. "There is nothing in the genre," he says, "that would sustain an 800-page Making of the English Working Class Blues." ${ }^{8}$ A collection of 'short stories' may be more apt.

Second, the 'key-words' according to which the 'thematic relations' would be established between the juxtaposed stories would be verbs rather than nouns. If, as James Clifford reminds us, identity is "a politics rather than an inheritance, ${ }^{, 49}$ then it is the verbs of prior politics rather than the nouns of subsequent outcomes that can most fruitfully open up insight into more just social relations. And if, as Grossberg reminds us, politics is about "moving people from where they are," ${ }^{50}$ this cannot be accomplished by celebrating a fixed identity. For example, rather than compare the historical experiences of women in several settings, or of indigenous peoples, or of unemployed men, or of imprisoned political dissidents, we might juxtapose stories of those who had been marginalized, or those who had been displaced, or those who had been tortured, or those who had been raped, or those who had been silenced, without respect to the standard organizing categories of gender, race, nationality or class. The historian should look for such stories far beyond her normal 'beat' of place and period - a tough task given that indexing practices follow the very categories she is trying to transcend. It has been my experience that dramatically different patterns of identification and of commitment follow from these reorganizations of historical subjects and historical questions. ${ }^{51}$

What has the potential to surprise us, in a 'verb-based juxtapositional history from below, ' is to see the relationship unsettled between stock stories, on the one hand, and stock characters, on the other. As one border-crosser between history and anthropology has put it, "We need to develop strategies for surprising ourselves, for looking at our material against the light. This calls for a 
constant scrutiny of the shopping lists and problem inventories we carry with us. "52 Someone similar to me in what he has done and had done to him, rather than the same as me in her gender, race and class positions, will provide an imaginative bridge to my membership in a collectivity of cosmopolitan solidarity. ${ }^{53}$ Articulating the bases of similarity across the global experience of subordination should be the first task of those seeking to mobilize for a project that is genuinely counter-hegemonic and socially just. This will avoid two fatal hazards to an effective mobilization: essentialism and the exaggeration of agency. Subordinates have, after all, a deficit of agency. That's what makes them subordinates.

The possible downside of juxtapositional history, as most historians would point out, is that the stories would be 'consumed' by the historian, and then redeployed, with what could at best be described as inadequate context. I would argue, however, that this very weakness could be a powerful political strength. As Benjamin has written,

There is nothing that commends a story to memory more effectively than that chaste compactness which precludes psychological analysis. And the more natural the process by which the storyteller forgoes psychological shading, the greater becomes the story's claim to a place in the memory of the listener, the more completely is it integrated into his own experience, the greater will be his inclination to repeat it to someone else someday, sooner or later. ${ }^{54}$

The more memorable it will be, too, for an audience beyond the typical readership of most historical monographs - fellow-historians who, it has been pointed out, are "unlikely, as a group, to bring about the changes we urge in the stories we tell.". 55

If, as Richard Rorty argues, solidarity is "a matter of imaginative identification with the details of others' lives, rather than a recognition of something antecedently shared," ${ }^{, 56}$ history from below can make important contributions to an emancipatory politics. This will only happen, however, as David Harvey urges, if such histories emphasize difference-producing practices themselves, rather than their outcomes in 'identities' or in static social locations. If this distinction has a familiar sound to socialists, reminding them of a well-understood emphasis on base rather than superstructure, on the material rather than the ideal, on the business end of things rather than on mere epiphenomena, that sense of recognition is not entirely misplaced. But note the verb here: reminding, not repeating. The differences which power produces, we now see clearly, can never be subsumed by 'class,' and the force with which they operate in our imag- 
inations has as sharp an edge and as long a life as the most material of weapons. The historian of emancipatory possibility may hope to interrupt those narratives of conformism which power-holders repeat and reinforce if, in juxtaposing subalterns' stories, she emulates Benjamin's ideal translator: "The basic error of the translator is that he preserves the state in which his own language happens to be instead of allowing his language to be powerfully affected by the foreign tongue. ... He must expand and deepen his language by means of the foreign language." ${ }^{57}$ Every account of subaltern harm, but particularly those we ourselves have not 'inherited,' may deepen our political language and sharpen our political praxis, if we but listen.

\footnotetext{
1 This work was carried out with the assistance of a grant from the Social Science and Humanities Research Council of Canada (Award No. 752-94-1680), whose support is gratefully acknowledged. It has grown out of a presentation to the Society for Socialist Studies at the Learned Societies Conference, Memorial University, St. John's, Nfld., June 9, 1997. I thank my fellow panel members (Rob Heynen. Peter Ives, Dennis Soron and Jeremy Stolow), as well as Professors Nicholas Rogers, Ioan Davies, and Judith Adler Hellman for inspiration and respectful critique.

${ }^{2}$ Immanuel Wallerstein, "The Construction of Peoplehood: Racism, Nationalism, Ethnicity," in Etienne Balibar and Immanuel Wallerstein, Race, Nation, Class: Ambiguous Identities (London 1991), 78.

${ }^{3}$ Walter Benjamin, Illuminations: Essay's and Reflections, Hannah Arendt, ed., Harry Zohn, trans. (New York 1968), 255.

${ }^{4}$ Michel de Certeau, "History: Ethics, Science, and Fiction," in Haan et al., eds. Social Science as Moral Inquiry (New York 1983), 130.

${ }^{5}$ Greg Dening, Performances (Chicago 1996), 37. An interesting challenge to the disingenuousness of the "widely accepted rule against presentism" is offered in Ellen Somekawa and Elizabeth A. Smith, "Theorizing the Writing of History or, I Can't Think Why It Should Be So Dull, For a Great Deal Of It Must Be Invention," Journal of Social History 22(1) (1988), 156-7.

${ }^{6}$ Cited in Christopher Hill, "The Poor and the People in Seventeenth-Century England," in Frederick Krantz, ed., Histony from Below: Studies in Popular Protest and Popular Ideology (Oxford 1988), 47.

${ }^{7}$ My characterization of the current conjuncture draws heavily on Arjun Appadurai, Modernity at Large: Cultural Dimensions of Globalization (Minneapolis 1996). On the increasing importance of sojourning as opposed to permanent migration, see Robin Cohen, Global Diasporas: An Introduction (Seattle 1997), 203, n. 4. I would differ with Appadurai on the overwhelming newness of globalization. John Holloway has forcefully reminded us that capitalism has always been global: "Capital, by its nature, knows no spatial bounds." John Holloway, "Global Capital and the National State," Capital \& Class 52 (1994), 30. And as Stuart Hall has framed the issue, "It has been going on since the Spanish and the Portuguese initiated the West's 'encounter' with the Rest at the end of the fifteenth century." Stuart Hall, "Culture, Community, Nation," Cultural Studies $7(3)$ (1993), 353.

${ }^{8}$ Raphael Samuel and Paul Thompson have pointed out historians' susceptibility to the
} 
myth of 'the nation.' "Introduction," The Myths We Live By (London 1990), 4. One commentator dates the beginning of this approach in the seventeenth century, with the Peace of Westphalia in 1648 which institutionalized the sovereign state as the primary focus of politics. He locates the origins of nationalism in England during this period. Bruce Mazlish, "An Introduction to Global History," in Bruce Mazlish and Ralph Buultjens, eds., Conceptualizing Global History (Boulder 1993), 9. Jonathan Rée, on the other hand, claims that the "logic of nationality" can be found in chronologies in the Middle Ages. "Internationality," Radical Philosophy 60 (Spring 1992), 7.

${ }^{9}$ For a comprehensive presentation of the accomplishments of the British contributors to this field, see two books by Harvey J. Kaye - The British Marxist Historians: An Introductory Analysis (Cambridge 1984), and The Education of Desire: Marxists and the Writing of History (New York 1992).

${ }^{10}$ See the moving tributes to Samuel by Stuart Hall, Sheila Rowbotham and Robin Blackburn in New Left Review 221 (1997), 119-38; Hall, NLR 221, 124.

11 "Editorial: Language and History," History Workshop Journal 10 (1980), 4.

${ }^{12}$ Dipesh Chakrabarty, "The Death of History? Historical Consciousness and the Culture of Late Capitalism," Public Culture 4(2) (1992), 52-3.

${ }^{13}$ Paul Gilroy, The Black Atlantic: Modemity and Double Consciousness (Cambridge Mass. 1993), 3-4.

${ }^{14}$ Robin Blackbum traces the roots of this orientation to the political conjuncture before WW II, referring to "the progressive English nationalism espoused by British communists in the Popular Front epoch and war years." Blackburn, NLR 1997, 134. Thompson was also notable later, however, for his scathing critiques of Continental social theory and its currency among British intellectuals (Perry Anderson, most prominently) whom he deemed too smitten with the allure of foreign products. He was criticized for "little Englandism," then, on this score, rather than on the basis of his state-bound historical narratives. See, for example, Rée, "Internationality," 7. While she is making a point about popular attitudes, not those of particular historians, Linda Colley has said that the postwar period in Britain, characterized by "imperial retreat," "fostered a highly introverted view of the British past." "Britishness and Otherness: An Argument," Journal of British Studies 31 (October 1992), 311. And while History Workshop Journal would applaud like-minded projects elsewhere ("he welcomed the emergence of barfuss historiker ... in Germany"), and while Samuel clearly recognized the importance of diasporic experience in formulating an emancipatory popular historiography, Rapheal Samuel and the HWJ collective stayed remarkably "close to home" in their subject matter. Blackburn, NLR 1997,135

${ }^{15}$ On many of these issues, see Joan Scott, Gender and the Politics of History (New York 1988). On rationality, for example, see 81 .

${ }^{16}$ Bryan D. Palmer, E. P. Thompson: Objections and Oppositions (London 1994), 11-13.

${ }^{17}$ See, for example, Elizabeth Fox-Genovese and Eugene D. Genovese, "The Political Crisis of Social History: A Marxian Perspective," Journal of Social History 10(2) (1976), 205-20, who criticize "history from the bottom up shorn of its political content," and Tony Judt, "A Clown in Regal Purple: Social History and the Historians," History' Workshop Journal 7 (1979), 66-94.

${ }^{18}$ Lawrence Grossberg, We Gotta Get Out of this Place: Popular Conservatism and Postmodern Culture (New York 1992), 364.

${ }^{19}$ Gilroy, Black Atlantic, 122-3.

${ }^{20}$ Peter Waterman, "Hidden from Herstory: Women, Feminism and New Global Solidarity," Economic and Political Weekly (October 30, 1993), WS-83-100.

${ }^{21}$ On the first of these presumptions, Ulf Hannerz, for example, has described the nineteenth-century roots of the idea that cultures are "territorial," that is, that "they belong to nations, regions, or localities," while Ernest Gellner defines nationalism as "a theory of 
political legitimacy" whereby a culturally-defined 'nation' ought to be congruent with a political unit. Ulf Hannerz, "Culture Between Center and Periphery: Toward a Macroanthropology," Ethnos 54 (III-IV) (1989), 201; Ernest Gellner, Nations and Nationalism (Oxford 1983), 1.

${ }^{22}$ Appadurai, Modernity at Large, 45.

${ }^{23}$ Ranajit Guha, "Preface," in Ranajit Guha, ed., Subaltern Studies I: Writings on South Asian History and Society (Delhi 1982), vii. See also, in the same volume, "On Some Aspects of the Historiography of Colonial India," 8. Here, while unfootnoted, Guha is quoting Gramsci, "Notes on Italian History." The passage quoted can be found in Quentin Hoare and Geoffrey Nowell Smith, eds., Selections from the Prison Notebooks of Antonio Gramsci (New York 1971), 55.

${ }^{24}$ Definitions from the Compact Edition of the Oxford English Dictionary. Karl Marx and Friedrich Engels, The Communist Manifesto (London 1967), 83. According to the OED, J.S. Mill made a similar point in his Political Economy in the same year. The OED further elaborates the particular usage of "cosmopolite" in nineteenth-century England as used in contrast to "patriot," "and so either reproachful or complimentary." My usage here is, then, decided 'complimentary.'

${ }^{25}$ As two anthropologists have put it, "if we question a pre-given world of separate and discrete 'peoples and cultures,' and see instead a difference-producing set of relations, we turn from a project of juxtaposing preexisting differences to one of exploring the construction of differences in historical process." Akhil Gupta and James Ferguson, "Beyond 'Culture': Space, Identity, and the Politics of Difference," Cultural Anthropology 7(1) (1992), 16.

${ }^{26}$ Peter Osborne, "Small-scale Victories, Large-scale Defeats: Walter Benjamin's Politics of Time," in Andrew Benjamin and Peter Osborne, eds., Walter Benjamin's Philosophy: Destruction and Experience (London 1994), 85.

${ }^{27}$ Holloway, "Global Capital," 27.

${ }^{28}$ Fox-Genovese and Genovese, "The Political Crisis," 219.

${ }^{29}$ De Certeau, "History," 131.

${ }^{30}$ Scott, Gender and the Politics of History, 8.

${ }^{31}$ Benedict Anderson, Imagined Communities: Reflections on the Origin and Spread of Nationalism, Revised Edition (London 1991), 163-85.

${ }^{32}$ Ernest Renan, "What is a Nation?" in Homi K. Bhabha, ed., Nation and Narration (London 1990), 11. Homi K. Bhabha, "DissemiNation: Time, Narrative, and the Margins of the Modern Nation," in Bhabha, ed., Nation and Narration, 311.

${ }^{33}$ Pierre Nora, "Between Memory and History: Les Lieux de Memoire," Representations 26 (1989), 7. On a similar point, see Roger I. Simon, "Forms of Insurgency in the Production of Popular Memories: The Columbus Quincentenary and the Pedagogy of Counter-Commemoration," Cultural Studies 7(1) (Jan 1993), 75.

${ }^{34}$ For two interesting discussions of 'non-events,' see George H. Lewis and Jonathan F. Lewis, "The Dog in the Night-time: Negative Evidence in Social Research," British Journal of Sociology 31(4) (1980), 544-58, and Raymond D. Fogelson, "The Ethnohistory of Events and Nonevents," Ethnohistory 36(2) (1989), 133-47.

${ }^{35}$ One example of problems in 'new-state-history' - one which may help us to understand the absence of the Albanian subaltern - has been described by Peter Burke, in his discussion of conflicts within a UNESCO project on world history, in which Greek, Albanian and Bulgarian historians insisted on organizing the treatment of their regions' history as if currently existing states were entities which could have their trajectories charted far back into the past. It was as if they were asking, as Burke put it, "to secede retrospectively from the Ottoman Empire." Peter Burke, "New Reflections on World History," Culture and History 5 (1989), 13.

${ }^{36}$ Gilroy, Black Atlantic, 4. 
37 Two excellent examples of Gilroy's approach to be found in history from below are Peter Linebaugh and Marcus Rediker, "The Many-Headed Hydra: Sailors, Slaves, and the Atlantic Working Class in the Eighteenth Century," Journal of Historical Sociology' 3(3) (1990), 225-52, and Marcus Rediker, Between the Devil and the Deep Blue Sea: Merchant Seamen, Pirates, and the Anglo-American Maritime World, 1700-1750 (Cambridge 1987). They are free of the lingering essentialisms that I think are detectable in Gilroy's work.

${ }^{38}$ Sir Arthur Conan Doyle, "Silver Blaze," The Memoirs of Sherlock Holmes (Harmondsworth 1950), 7-34.

${ }^{39}$ Jonathan Rée has pointed out that Hobsbawm has "always been conspicuous for his unswerving communist internationalism," but I think the internationalism might be seen as reinforced by this particularly cosmopolitan linguistic ability. Rée, "Internationality," 7.

${ }^{40}$ I have explored some of these issues in a 1994 unpublished paper, "States, Communities and the Contemporary Politicization of Ethnicity: The Case of the Miskito Coast."

${ }^{41}$ Michel-Rolph Trouillot, "The Caribbean Region: An Open Frontier in Anthropological Theory," Annual Review of Anthropology 21 (1992), 33.

${ }^{42}$ Eric Hobsbawm and Terence Ranger, eds., The Invention of Tradition (Cambridge 1983).

$\$ 3$ George Lakoff and Mark Johnson, Metaphors We Live By (Chicago 1980), 10.

${ }^{44}$ Fogelson, "Events and Nonevents," 141.

${ }^{45}$ Grossberg, Popular Conservatism, 379.

${ }^{46}$ David Harvey, "Class Relations, Social Justice and the Politics of Difference," in Keith and Pile, eds., Place and the Politics of Identity, 64.

${ }^{47}$ I draw inspiration here from Marcus and Clifford's technique of "defamiliarization by cross-cultural juxtaposition." George E. Marcus and Michael M. J. Fischer, Anthropology as Cultural Critique (Chicago 1986), 137-8 and 157-64. I'm grateful to Robert Heynen for reminding me of the relevance of this work to my own.

${ }^{48}$ Richard T. Vann, "The Rhetoric of Social History," Journal of Social History 10(2) (1976), 232.

${ }^{49}$ James Clifford, "Traveling Cultures," in Lawrence Grossberg et al., eds., Cultural Studies (New York 1992), 116.

${ }^{50}$ Grossberg, Popular Conservatism, 371

${ }^{51}$ I am now revising a work of my own in 'verb-based juxtapositional history from below,' with the working title 'Death and the Matron: Rethinking 'History from Below' through the Politics of Widowhood.'

52 Orvar Lofgren, "Colonizing the Territory of Historical Anthropology," Culture and History 1 (1986), 23.

${ }^{53}$ Michael Keith and Steve Pile, "Introduction," in Keith and Pile, eds., Place and the Politics of Identity (London 1993), 38.

${ }^{54}$ Benjamin, Illuminations, 91 .

55 Somekawa and Smith, "Theorizing the Writing of History," 157.

${ }^{56}$ Richard Rorty, Contingency; Irony, Solidarity' (Cambridge 1989), 190.

${ }^{57}$ Benjamin, "The Task of the Translator," Illuminations, 81. 